University of Nebraska - Lincoln

DigitalCommons@University of Nebraska - Lincoln

Publications from USDA-ARS / UNL Faculty

U.S. Department of Agriculture: Agricultural

Research Service, Lincoln, Nebraska

2009

\title{
Sorption of Phosphorus from Swine, Dairy, and Poultry Manures
}

\author{
Carl H. Bolster \\ United States Department of Agriculture-Agricultural Research Service, carl.bolster@ars.usda.gov \\ Karamat R. Sistani \\ United States Department of Agriculture-Agricultural Research Service
}

Follow this and additional works at: https://digitalcommons.unl.edu/usdaarsfacpub

Part of the Agricultural Science Commons

Bolster, Carl H. and Sistani, Karamat R., "Sorption of Phosphorus from Swine, Dairy, and Poultry Manures" (2009). Publications from USDA-ARS / UNL Faculty. 520.

https://digitalcommons.unl.edu/usdaarsfacpub/520

This Article is brought to you for free and open access by the U.S. Department of Agriculture: Agricultural Research Service, Lincoln, Nebraska at DigitalCommons@University of Nebraska - Lincoln. It has been accepted for inclusion in Publications from USDA-ARS / UNL Faculty by an authorized administrator of DigitalCommons@University of Nebraska - Lincoln. 


\title{
Sorption of Phosphorus from Swine, Dairy, and Poultry Manures
}

\author{
Carl H. Bolster and Karamat R. Sistani \\ U.S. Department of Agriculture-Agricultural Research Service, Animal Waste \\ Management Research Unit, Bowling Green, Kentucky, USA
}

\begin{abstract}
In most phosphorus (P) sorption studies, $\mathrm{P}$ is added as an inorganic salt to a predefined background solution such as calcium chloride $\left(\mathrm{CaCl}_{2}\right)$ or potassium chloride $(\mathrm{KCl})$; however, in many regions, the application of $\mathrm{P}$ to agricultural fields is in the form of animal manure. The purpose of this study, therefore, was to compare the sorption behavior of dissolved reactive $\mathrm{P}$ (DRP) in monopotassium phosphate $\left(\mathrm{KH}_{2} \mathrm{PO}_{4}\right)$-amended $\mathrm{CaCl}_{2}$ and $\mathrm{KCl}$ solutions with sorption behavior of DRP in three different animal manure extracts. Phosphorus single-point isotherms (PSI) were conducted on eight soils with the following solutions: $\mathrm{KH}_{2} \mathrm{PO}_{4}$-amended $0.01 \mathrm{M} \mathrm{CaCl}_{2}$ solution, $\mathrm{KH}_{2} \mathrm{PO}_{4}$-amended $0.03 \mathrm{M}$ $\mathrm{KCl}$ solution, water-extracted dairy manure, water-extracted poultry litter, and swine lagoon effluent. The PSI values for the dairy manure extract were significantly lower than the $\mathrm{CaCl}_{2}$ solution for all eight soils and lower than the $\mathrm{KCl}$ solution for six soils. The PSI values were significantly higher, on the other hand, for poultry litter extract and swine effluent than the inorganic solutions in four and five of the soils, respectively. Our observations that the sorption of DRP in manure solutions differs significantly from that of $\mathrm{KH}_{2} \mathrm{PO}_{4}$-amended $\mathrm{CaCl}_{2}$ and $\mathrm{KCl}$ solutions indicates that manure application rates based on sorption data collected from inorganic $\mathrm{P}$ salt experiments may be inaccurate.
\end{abstract}

Keywords: Animal manure, phosphorus sorption, PSI, single-point isotherms

This article is a U.S. government work, and is not subject to copyright in the United States.

This article is not subject to U.S. copyright law.

Received 30 May 2007, Accepted 2 September 2007

Address correspondence to Carl H. Bolster, USDA-ARS, AWMRU, 230

Bennett Ln, Bowling Green, KY 42104, USA. E-mail: carl.bolster@ars.usda.gov 


\section{INTRODUCTION}

The indiscriminant application of fertilizers and manures to crop and pasture lands has resulted in excess nutrients being transported from agricultural fields to ground and surface waters (Sauer et al. 2000). Once applied to the surface, nutrients from fertilizers or manures can be lost through surface runoff or through leaching below the root zone and into groundwater reservoirs. When nutrient-enriched waters reach surface waters, whether through surface or subsurface pathways, eutrophication is often the result, ultimately leading to depleted dissolved oxygen (DO) concentrations within the water column. In freshwater environments, the nutrient of primary concern is phosphorus (P) (Parry 1998). Although considerable research has been undertaken to identify ways to prevent $\mathrm{P}$ loss from agricultural fields, $\mathrm{P}$ contamination of freshwater systems by surface and subsurface pathways is still a significant concern. Therefore, a better understanding of the factors controlling P mobility through the landscape is needed.

Phosphorus mobility in the environment is controlled to a large extent by its sorption to soil. Because soil has a finite capacity to sorb P, there is much interest in obtaining accurate estimates of a soil's ability to bind additional $\mathrm{P}$. An approach gaining popularity for estimating a soil's capacity to retain $\mathrm{P}$ is the calculation of a saturation index, sometimes referred to as the degree of $\mathrm{P}$ saturation (DPS) (Hooda et al. 2000; Kleinman and Sharpley 2002). The DPS is a ratio of extractable P to P sorption capacity and thus quantifies the remaining sorption capability of the soil. If the DPS is high, then the soil is nearing saturation and presumably cannot bind much additional $\mathrm{P}$ and therefore is at risk for $\mathrm{P}$ loss. In contrast, a soil with a low DPS has a greater ability to bind P, and therefore little $\mathrm{P}$ is expected to be released from the soil. A reliable estimate of a soil's potential for P loss is therefore dependent on accurate estimates of the amount of $\mathrm{P}$ sorbed to the soil and the $\mathrm{P}$ sorption capacity of the soil.

The $\mathrm{P}$ sorption capacity of a soil is often determined through the use of sorption studies where a known mass of soil is equilibrated with a solution of known $\mathrm{P}$ concentration. After equilibration, the concentration remaining in solution is measured and used to calculate the concentration sorbed to the soil. In most cases, sorption studies are conducted by adding known concentrations of inorganic $\mathrm{P}$ in a predefined medium such as calcium chloride $\left(\mathrm{CaCl}_{2}\right)$ or potassium chloride (KCl) (Borling, Otabbong, and Barberis 2001; D'Angelo et al. 2003; Kleinman and Sharpley 2002; Nair et al. 1984; Reddy et al. 1980; Sharpley 1995; Siddique and Robinson 2003). A potential limitation to this approach, however, is that in many regions the application of $\mathrm{P}$ to agricultural fields is in the form of animal manure. Because manure leachate differs significantly in composition from a $\mathrm{CaCl}_{2}$ or $\mathrm{KCl}$ 
solution, it is unlikely that sorption parameters obtained using a $\mathrm{CaCl}_{2}$ or $\mathrm{KCl}$ matrix will be representative of the sorption, and by extension transport, of manure $\mathrm{P}$ in the environment. Indeed, differences in the sorption and mobility of manure $\mathrm{P}$ as compared to inorganic $\mathrm{P}$ have been observed in several studies (Campbell and Racz 1975; Eghball, Binford, and Baltensperger 1996; Jensen et al. 2000; Marshall and Laboski 2006; McDowell and Sharpley 2004; Redding, Shatte, and Bell 2006; Robinson and Sharpley 1996; Siddique and Robinson 2003).

Important differences between manure and $\mathrm{CaCl}_{2}$ and $\mathrm{KCl}$ solutions expected to affect $\mathrm{P}$ sorption to soils include manure organic-matter content, $\mathrm{pH}$, and ionic composition (Berkheiser et al. 1980). The presence of organic matter can alter $\mathrm{P}$ sorption behavior by competing for sorption sites, causing the dissolution of aluminum ( $\mathrm{Al})$ and iron $(\mathrm{Fe})$ oxides, increasing the overall negative charge at the surface, and serving as a site for P sorption (Guppy et al. 2005b; Ohno and Crannell 1996). Soil solution $\mathrm{pH}$ affects $\mathrm{P}$ sorption by controlling the surface electrostatic potential, the dominant orthophosphate species in solution, and charge sign and magnitude of $\mathrm{Fe}$ and Al coatings (Bowden et al. 1980). Ionic composition affects $\mathrm{P}$ sorption through the precipitation of calcium phosphates in solutions with high concentrations of calcium $(\mathrm{Ca})$ (Barrow et al. 1980; Naidu et al. 1990) and through cation-induced changes in surface electrostatic potential (Curtin, Syers, and Bolan 1992).

In the work reported here, we set out to determine what effect $\mathrm{P}$ source [manure vs. monopotassium phosphate $\left(\mathrm{KH}_{2} \mathrm{PO}_{4}\right)$ ] and solution matrix (manure extract, $\mathrm{CaCl}_{2}$, or $\mathrm{KCl}$ ) has on the sorption behavior of $\mathrm{P}$ to eight different soil types. We addressed this question by comparing the results of single-point $\mathrm{P}$ addition experiments conducted with $\mathrm{KH}_{2} \mathrm{PO}_{4}$ in $0.01 \mathrm{M} \mathrm{CaCl}_{2}$ and $0.03 \mathrm{M} \mathrm{KCl}$ solutions with those conducted in animal manure extracts. Our results will help determine whether sorption parameters obtained using an inorganic salt medium are representative of sorption behavior of $\mathrm{P}$ when it is applied in the form of animal manure.

\section{MATERIALS AND METHODS}

\section{Soil Analysis}

Surface soil samples $(0-15 \mathrm{~cm})$ were collected at seven locations in western Kentucky and one location in Alabama representing eight different soils series as follows: Belknap (Fluvaquentic Endoaquepts), Collins (Aquic Udifluvents), Hartsells (Typic Hapludults), Lakin (Lamellic Udipsamments), Loring (Oxiaquic Fragiudalfs), Melvin (Fluvaquentic Endoaquepts), Pembroke (Mollic Paleudalfs), and 
Zanesville (Oxiaquic Fragiudalfs). Soils were air dried and passed through a 2-mm sieve prior to use. Soil $\mathrm{pH}$ was determined in a 1:1 soil-to-water ratio, and particle size was determined using the pipette method. Percent carbon and nitrogen were determined by loss on ignition with a carbon (C)/ $\mathrm{N}$ analyzer (Elementar Americas Inc., Mt. Laurel, NJ).

Air-dried soils were subjected to both oxalate and Mehlich 3 extractions. Oxalate extractions were performed by adding $2.5 \mathrm{~g}$ of soil to $50 \mathrm{ml}$ oxalate extraction solution $(0.175 \mathrm{M}$ ammonium oxalate $+0.1 \mathrm{M}$ oxalic acid). The mixtures were placed on a reciprocating shaker in the dark for $2 \mathrm{~h}$, then centrifuged at $3500 \mathrm{rpm}$ for $10 \mathrm{~min}$. Mehlich 3 extractions were performed by adding $2 \mathrm{~g}$ soil to $20 \mathrm{ml}$ Mehlich 3 solution (Mehlich 1984). The mixture was placed on a reciprocating shaker for $10 \mathrm{~min}$, followed by centrifugation at $3500 \mathrm{rpm}$ for $10 \mathrm{~min}$. All extractions were filtered through Whatman no. 42 filter paper and analyzed using inductively coupled plasma optical emission spectroscopy (ICP-OES) (Varian, Walnut Creek, Calif.). Total P was determined by microwave digestion of $0.25 \mathrm{~g}$ of soil in nitric acid.

\section{Manure Solution and Analysis}

Three types of manure solutions were used in this study: swine lagoon effluent, poultry litter extract, and dairy cow manure extract. Swine lagoon effluent was collected at the surface of a swine lagoon located on the farm of Western Kentucky University. Poultry litter and dairy cow manure extracts were obtained by adding approximately $7 \mathrm{~g}$ of litter or manure into $700 \mathrm{~mL}$ distilled water (DIW) and placing the mixture on a roller for $24 \mathrm{~h}$. Liquid manure was centrifuged at $10,000 \mathrm{rpm}$ for $15 \mathrm{~min}$, then filtered through a $0.45-\mu \mathrm{m}$ filter prior to use. Specific conductivity $(\mathrm{SpC})$ was measured with a YSI 556 Multi-probe System (YSI Environmental, Yellow Springs, Ohio) and converted to ionic strength using the equation of Griffen and Jurinak (1973). The $\mathrm{pH}$ of the manure solutions was measured using an Orion combination $\mathrm{pH}$ probe (Thermo Electron Corp., Beverly, Mass.). Cations and total dissolved $\mathrm{P}$ were analyzed in triplicate using ICP-OES. Dissolved reactive $\mathrm{P}$ (DRP) was measured colorimetrically (Murphy and Riley 1962) using a QuickChem Autoanalyzer (Lachat Instruments, Chicago, Ill.). Dissolved organic carbon was determined by loss on ignition.

\section{Single-Point P Additions}

Sorption behavior of the soils was quantified by calculating a single-point $\mathrm{P}$ sorption index (PSI) for each soil with each solution matrix. The solutions used included $0.01 \mathrm{M} \mathrm{CaCl}_{2}$ solution amended with $\mathrm{KH}_{2} \mathrm{PO}_{4}$ (Nair et al. 1984), $0.03 \mathrm{M} \mathrm{KCl}$ solution (equivalent ionic strength of 
$0.01 \mathrm{M} \mathrm{CaCl}_{2}$ ) amended with $\mathrm{KH}_{2} \mathrm{PO}_{4}$, water-extracted dairy manure, water-extracted poultry litter, and swine lagoon effluent. The initial DRP concentration averaged $13.5 \mathrm{mg} \mathrm{L}^{-1}$ for the five solutions, resulting in an

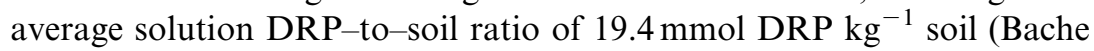
and Williams 1971; Borling, Otabbong, and Barberis 2001). Each manure solution was diluted appropriately to obtain the proper initial DRP concentration. In the poultry and swine solutions, DRP was significantly less than total $\mathrm{P}$ in solution; therefore, the total $\mathrm{P}$ applied to the soil was greater for these two solutions. Approximately $0.9 \mathrm{~g}$ of soil was mixed with $40 \mathrm{ml}$ of each solution and placed in $50-\mathrm{ml}$ centrifuge tubes. The centrifuge tubes were placed on a reciprocating shaker and allowed to equilibrate for $24 \mathrm{~h}$ at room temperature. Following equilibration, the suspension was centrifuged at $4000 \mathrm{rpm}$ for $10 \mathrm{~min}$, and the liquid was decanted and filtered through a $0.45-\mu \mathrm{m}$ filter (Whatman). The PSI for each soil was calculated as the ratio of sorbed DRP (as determined by difference between initial and equilibrium P) to log DRP concentration remaining in solution (Bache and Williams 1971). All single-point $P$ addition experiments were performed in triplicate.

\section{Statistical Analysis}

Single-factor analysis of variance (ANOVA) was used to test for differences between PSI values measured for the different solution treatments for each soil. Mean separations were performed using Fisher's least significant difference (LSD) method. Linear regression analyses were performed to determine if PSI values were significantly correlated with any of the measured soil parameters. All statistical analyses were performed using SAS 9.1 (SAS Institute 2003). Differences were considered significant at $P<0.05$.

\section{RESULTS AND DISCUSSION}

A wide range in physical and chemical characteristics was observed for the eight soils used in our study (Table 1). Soil $\mathrm{pH}$ values ranged from 4.6 to nearly 7, and the sand content ranged from 4 to $62 \%$. Mehlich 3extractable $\mathrm{P}$ ranged from 3.6 to $94.9 \mathrm{mg} \mathrm{kg}^{-1}$ soil, and total $\mathrm{P}$ ranged from 80 to nearly $460 \mathrm{mg} \mathrm{kg}^{-1}$. In general, total soil $\mathrm{P}$ was significantly less than that reported in Kentucky soils by D'Angelo et al. (2003), suggesting that these soils had limited applications of $\mathrm{P}$. There was a strong curvilinear relationship between Mehlich $3-$ and oxalateextractable $\mathrm{P}\left(\ln \mathrm{P}_{\mathrm{M} 3}=0.019 \times \mathrm{P}_{\mathrm{ox}}+0.734 ; \mathrm{R}^{2}=0.94\right)$, consistent with the findings of D'Angelo et al. (2003). 
Table 1. Selected soil chemical and physical properties

\begin{tabular}{|c|c|c|c|c|c|c|c|c|c|c|c|c|c|c|}
\hline \multirow{2}{*}{$\begin{array}{l}\text { Soil } \\
\text { series }\end{array}$} & \multirow[t]{2}{*}{ pH } & \multirow{2}{*}{$\begin{array}{c}\text { Bulk } \\
\text { density } \\
\left(\mathrm{g} \mathrm{cm}^{-3}\right)\end{array}$} & \multirow{2}{*}{$\begin{array}{c}\text { Total C } \\
(\%)\end{array}$} & \multirow{2}{*}{$\begin{array}{c}\text { Total P } \\
\left(\mathrm{mg} \mathrm{kg}^{-1}\right)\end{array}$} & \multirow{2}{*}{$\begin{array}{l}\text { Sand/silt/ } \\
\text { clay }(\%)\end{array}$} & \multicolumn{4}{|c|}{ Oxalate-extractable } & \multicolumn{5}{|c|}{ Mehlich-3 Extractable } \\
\hline & & & & & & $\underset{\left(\mathrm{mg} \mathrm{kg}^{-1}\right)}{\mathbf{P}}$ & $\underset{\left(\mathrm{mg} \mathrm{kg}^{-1}\right)}{\mathbf{A l}}$ & $\begin{array}{c}\mathbf{F e} \\
\left(\mathrm{mg} \mathrm{kg}^{-1}\right)\end{array}$ & $\begin{array}{c}\operatorname{DPS}^{a} \\
(\%)\end{array}$ & $\underset{\left(\mathrm{mg} \mathrm{kg}^{-1}\right)}{\mathbf{P}}$ & $\underset{\left(\mathrm{mg} \mathrm{kg}^{-1}\right)}{\mathbf{A l}}$ & $\begin{array}{c}\mathbf{F e} \\
\left(\mathrm{mg} \mathrm{kg}^{-1}\right)\end{array}$ & $\begin{array}{c}\mathbf{C a} \\
\left(\mathrm{mg} \mathrm{kg}^{-1}\right)\end{array}$ & $\begin{array}{c}\operatorname{DPS}^{a} \\
(\%)\end{array}$ \\
\hline Belknap & 4.61 & 2.25 & 1.03 & 394 & $19 / 69 / 12$ & 155 & 404 & 1274 & 9.20 & 34.1 & 701 & 142 & 479 & 4.05 \\
\hline Collins & 6.40 & 2.05 & 1.50 & 459 & $4 / 81 / 15$ & 181 & 500 & 841 & 13.47 & 62.1 & 609 & 80.6 & 1432 & 9.00 \\
\hline Hartsells & 5.68 & 1.71 & 0.614 & 80.1 & $60 / 30 / 10$ & 15.6 & 385 & 160 & 2.86 & 3.92 & 565 & 32.7 & 379 & 0.66 \\
\hline Lakin & 6.96 & 2.36 & 0.928 & 450 & $62 / 28 / 10$ & 204 & 509 & 824 & 15.27 & 94.9 & 593 & 107 & 1759 & 13.56 \\
\hline Loring & 5.34 & 1.93 & 1.35 & 252 & 8/80/12 & 49.4 & 429 & 1191 & 3.05 & 3.61 & 727 & 104 & 889 & 0.43 \\
\hline Melvin & 5.49 & 2.28 & 0.932 & 249 & $12 / 67 / 21$ & 91.2 & 243 & 1151 & 6.54 & 17.8 & 503 & 163 & 1355 & 2.67 \\
\hline Pembroke & 5.70 & 1.31 & 1.30 & 350 & $8 / 70 / 22$ & 114 & 690 & 908 & 7.12 & 27.1 & 613 & 33.1 & 1193 & 4.20 \\
\hline Zanesville & 5.34 & 1.93 & 1.40 & 251 & $7 / 74 / 19$ & 35.3 & 601 & 1148 & 2.02 & 2.72 & 900 & 106 & 991 & 0.27 \\
\hline
\end{tabular}

${ }^{a}$ The degree of phosphorus sorption (DPS) was calculated by dividing the extractable P content by the sum of the extractable Fe and Al contents of the soil. 
Table 2. Selected characteristics of the different $\mathrm{P}$ solutions (standard deviations are in parentheses)

\begin{tabular}{lccccc}
\hline Parameter & $\begin{array}{c}0.01 \mathrm{M} \\
\mathrm{CaCl}_{2}\end{array}$ & $\begin{array}{c}0.03 \mathrm{M} \\
\mathrm{KCl}\end{array}$ & $\begin{array}{c}\text { Dairy } \\
\text { manure }\end{array}$ & $\begin{array}{c}\text { Poultry } \\
\text { litter }\end{array}$ & $\begin{array}{c}\text { Swine } \\
\text { effluent }\end{array}$ \\
\hline $\mathrm{pH}$ & 5.20 & 5.08 & 7.39 & 8.12 & 8.40 \\
$\mathrm{IS}\left(\mathrm{mmol} \mathrm{L}^{-1}\right)^{a}$ & $(0.0058)$ & $(0.0011)$ & $(0.044)$ & $(0.006)$ & $(0.16)$ \\
& 30.5 & 30.5 & 5.6 & 23.5 & 24.1 \\
$\mathrm{DOC}\left(\mathrm{mg} \mathrm{L}^{-1}\right)$ & 0 & 0 & $(0.0013)$ & $(1.4)$ & $(0.0026)$ \\
& & 310 & 270 & 45 \\
$\mathrm{DRP}\left(\mathrm{mg} \mathrm{L}^{-1}\right)$ & 13.9 & 14.0 & $(7.1)$ & $(11)$ & $(1.7)$ \\
& $(0.0614)$ & $(0.050)$ & $(0.083)$ & $(0.056)$ & $(0.030)$ \\
$\mathrm{TP}\left(\mathrm{mg} \mathrm{L}^{-1}\right)$ & 14.1 & $\mathrm{ND}$ & 19.1 & 16.4 & 12.9 \\
& $(0.0880)$ & & $(0.210)$ & $(0.196)$ & $(0.146)$ \\
$\mathrm{Al}\left(\mathrm{mg} \mathrm{L}^{-1}\right)$ & 0 & 0 & 0.648 & 0.138 & 0.018 \\
& & & $(0.0033)$ & $(0.182)$ & $(0.0049)$ \\
$\mathrm{Ca}\left(\mathrm{mg} \mathrm{L}^{-1}\right)$ & 400 & 0 & 38 & 5.9 & 53 \\
& & & $(0.13)$ & $(0.10)$ & $(0.36)$ \\
$\mathrm{Fe}\left(\mathrm{mg} \mathrm{L}^{-1}\right)$ & 0 & 0 & 0.30 & 0.51 & 0.058 \\
$\mathrm{~K}\left(\mathrm{mg} \mathrm{L}^{-1}\right)$ & 17 & 1200 & $(0.0051)$ & $(0.11)$ & $(0.0048)$ \\
& $(0.23)$ & & $(0.19)$ & $(15)$ & $(0.48)$ \\
$\mathrm{Mg}\left(\mathrm{mg} \mathrm{L}^{-1}\right)$ & 0 & 0 & 21 & 11 & 35 \\
$\mathrm{Mn}\left(\mathrm{mg} \mathrm{L}^{-1}\right)$ & & & $(0.094)$ & $(0.16)$ & $(0.063)$ \\
$\mathrm{Na}\left(\mathrm{mg} \mathrm{L}^{-1}\right)$ & 0 & 0 & 0.43 & 0.093 & 0.14 \\
& & & $(0.003)$ & $(0.003)$ & $(0.001)$ \\
& & 0 & 0.61 & 47 & 45 \\
& & & $(0.021)$ & $(0.46)$ & $(0.64)$ \\
\hline
\end{tabular}

${ }^{a}$ Ionic strength (IS) for the manure solutions was calculated from measurements of specific conductivity $(\mathrm{SpC})$ by the equation: IS $\left(\mathrm{mmol} \mathrm{L}^{-1}\right)=\mathrm{SpC}$ $\left(\mu \mathrm{sm}^{-1}\right) \times 0.013$ (Griffin and Jurinak 1973).

The $\mathrm{pH}$, ionic composition, and DOC content varied noticeably among the different manure solutions (Table 2). For example, DOC was highest for the dairy manure extract $\left(310 \mathrm{mg} \mathrm{L}^{-1}\right)$ and lowest for the swine effluent $\left(45 \mathrm{mg} \mathrm{L}^{-1}\right)$. Conversely, $\mathrm{pH}$ was highest for the swine effluent (8.40) and lowest for the dairy manure (7.39). The dairy manure extract contained the highest or second highest concentrations of the major cations $\mathrm{Ca}$, potassium $(\mathrm{K})$, magnesium $(\mathrm{Mg})$, and sodium $(\mathrm{Na})$ yet had the lowest IS. The DRP constituted $100 \%$ of the total P in the swine effluent, whereas for the poultry litter and dairy manure extracts the percentages were $82 \%$ and $69 \%$, respectively (Table 2 ). These numbers compare well with Robinson and Sharpley (1996) who observed DRP constituting $85 \%$ of TP in poultry litter, and Sharpley and Moyer (2000), who reported DRP constituting only $63 \%$ of TP in dairy manure. 
The sorption of $\mathrm{P}$, as measured by PSI, was a function of both soil and solution type (Figure 1). The Lakin soil tended to have the lowest PSI values, whereas the Zanesville soil had the highest PSI values for all solution types. Although PSI values varied significantly between solution types, the strongest single predictor of PSI for all solution types was the Mehlich 3 aluminum (Al) content of the soil (Figure 2). Surprisingly, the slopes of the regression lines between PSI and Mehlich $3 \mathrm{Al}$ were not statistically different in the five different solution treatments $(P<0.05)$. It is not uncommon for metal oxides to play a strong role in $\mathrm{P}$ sorption in noncalcareous soils (Berkheiser et al. 1980; Hsu 1964; Van der Zee and Van Riemsdijk 1986), though unlike our study most of these correlations have been observed with oxalate-extractable Al instead of Mehlich 3extractable Al (Beauchemin et al. 2003; Borggaard et al. 1990; Borling, Otabbong, and Barberis 2001; Burkitt et al. 2006; Kleinman and Sharpley 2002; Pierzynski et al. 1990; Traina et al. 1986).

For all soils, the PSI values for the dairy manure extract were significantly lower $(P<0.05)$ than for the $\mathrm{CaCl}_{2}$, poultry litter extract, and swine lagoon effluent solutions and was significantly lower than the

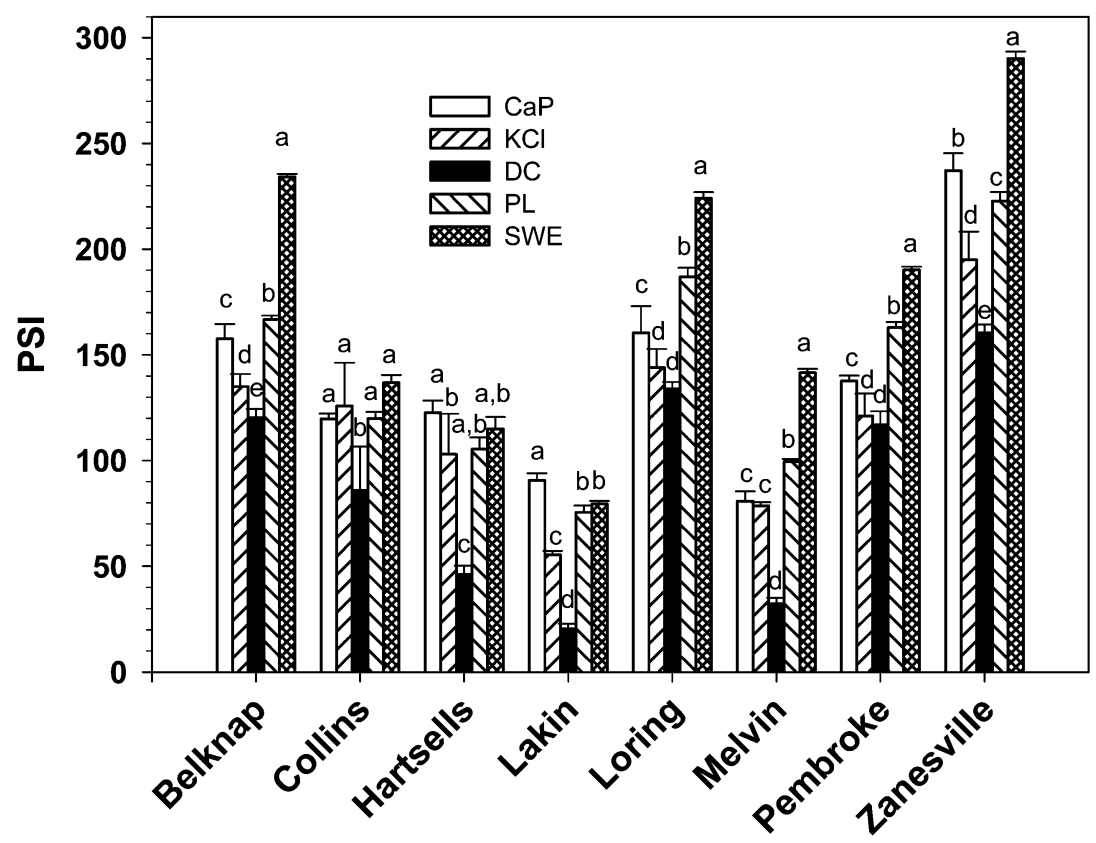

\section{Soil Type}

Figure 1. Bar graph showing PSI values measured for each soil and solution type. Different letters within each soil type denote statistically significant differences $(P<0.05 ; \mathrm{n}=3)$. 


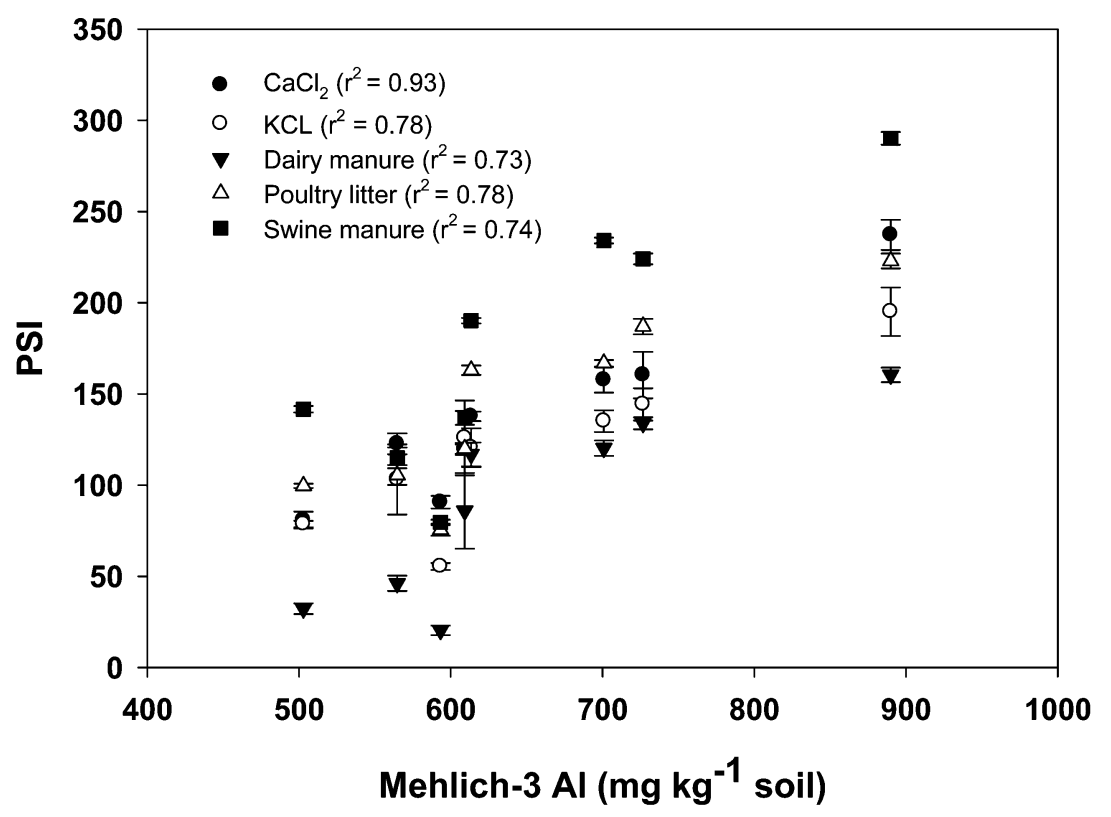

Figure 2. Correlation between PSI values and Mehlich 3-extractable Al.

$\mathrm{KCl}$ solution for six of the eight soils (Figure 1). Conversely, PSI values for the swine effluent were significantly higher than for the other four solutions in five of the eight soils tested. The PSI values for the poultry litter extract exceeded $\mathrm{KCl}$ and $\mathrm{CaCl}_{2}$ PSI values in four of the soils. For the Collins and Hartsells soils, the PSI values for the poultry litter and swine effluent were not statistically different than the PSI values observed for the $\mathrm{CaCl}_{2}$ and $\mathrm{KCl}$ solutions, whereas for the Lakin soil, the PSI values for these two manure solutions were greater than the $\mathrm{KCl}$ solution but less than the $\mathrm{CaCl}_{2}$ solution. The DRP sorption in the $\mathrm{CaCl}_{2}$ solution was significantly higher in six soils and not significantly different in two soils than in the $\mathrm{KCl}$ solution.

Our results indicate that the presence of manure can either inhibit or enhance DRP sorption depending on soil and manure type, similar to those findings reported elsewhere. For instance, Siddique and Robinson (2003) compared the $\mathrm{P}$ sorption capacity of five different soils following incubation with different sources of $\mathrm{P}$ including poultry litter, cattle slurry, and $\mathrm{KH}_{2} \mathrm{PO}_{4}$. Compared to the $\mathrm{KH}_{2} \mathrm{PO}_{4}$, the $\mathrm{P}$ sorption maximum was observed to increase for the poultry litter treatment but decrease for the cattle slurry treatment. Marshall and Laboski (2006) observed an increase in DRP sorption capacity with dairy slurry and a decrease in DRP sorption capacity with swine slurry as compared to $\mathrm{KH}_{2} \mathrm{PO}_{4}$-amended $\mathrm{KCl}$ solution. Redding, Shatte, and Bell (2006) also 
observed manure effluent to either increase or decrease $\mathrm{P}$ sorption depending on the soil type.

In addition to DRP, sorption of organic matter (as measured by DOC) was also measured. For the most part, the amount of DOC sorbed to the soils was similar between the dairy and poultry extracts and with little or no DOC sorption occurring with the swine effluent (Figure 3). The large amount of sorption of DOC in the dairy manure solution may explain why DRP sorption was much lower in this solution compared to the $\mathrm{CaCl}_{2}$ and $\mathrm{KCl}$ solutions. Organic matter has been shown to reduce $\mathrm{P}$ sorption to soils by competing with $\mathrm{P}$ for sorption sites as well as complexing with metal oxyhydroxides (Bhatti, Comerford, and Johnston 1998; Ohno and Crannell 1996; Ohno and Erich 1997; Singh and Jones 1976; Violante, Colombo, and Buondonno 1991). On the other hand, studies have also reported increased $\mathrm{P}$ sorption due to the presence of organic matter (Guppy et al. 2005a; Harter 1969; Redding, Shatte, and

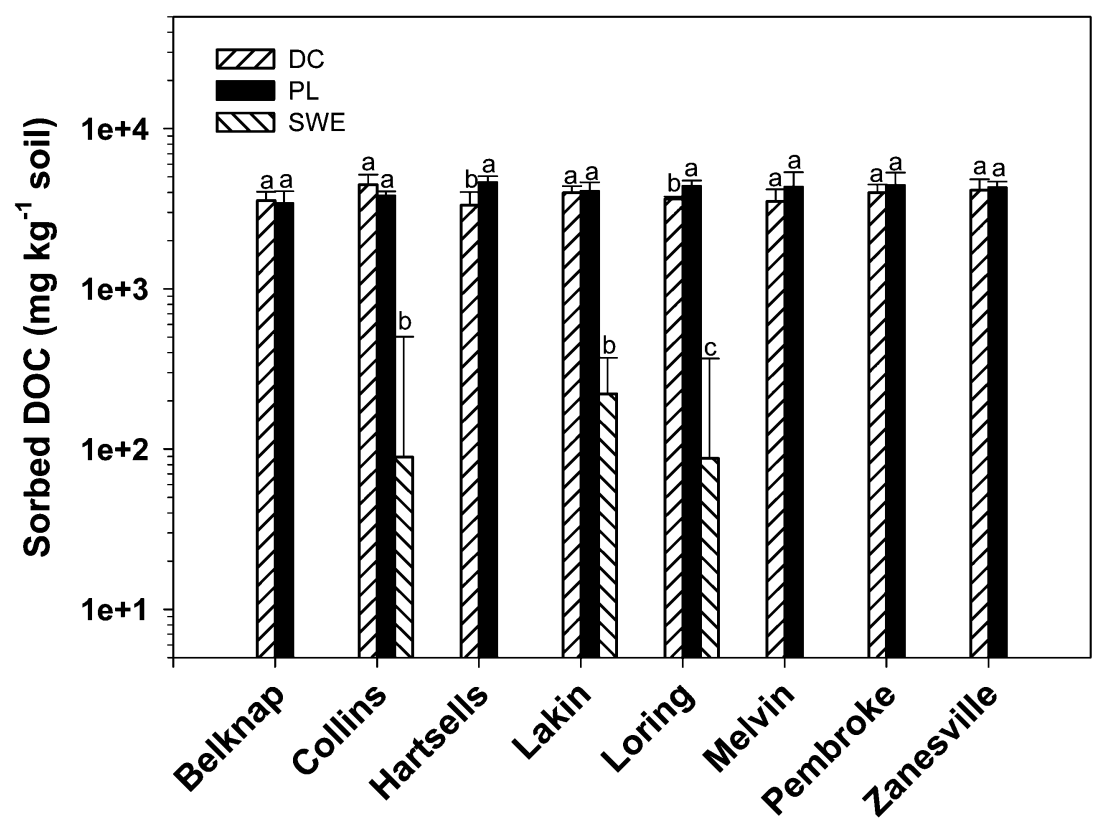

\section{Soil Type}

Figure 3. Bar graph showing DOC sorption $\left(\mathrm{mg} \mathrm{kg}^{-1}\right.$ soil) measured for each soil and solution type following a 24-h equilibration period. Sorption of DOC was only observed in the Collins, Lakin, and Loring soil series with the swine effluent solution. Different letters within each soil type denote statistically significant differences $(P<0.05 ; \mathrm{n}=3)$. 
Bell 2006; Sanyal, De Datta, and Chan 1993). Possible mechanisms include the attachment of $\mathrm{P}$ to DOM through metal-chelate linkages (Guppy et al. 2005a; Zhou, Rhue, and Harris 1997) or inhibiting metal oxide crystallization (Borggaard et al. 1990). It is possible, therefore, that organic matter may have played a role in the enhanced sorption observed for the poultry litter solution in four of the soils.

Studies have shown that the effect of DOM on P sorption is complex and likely varies depending on the type and quality of the organic matter (Bolan et al. 1994; Fox, Comerford, and McFee 1990; Ohno and Crannell 1996; Sibanda and Young 1986; Violante and Huang 1989). For instance, Singh and Jones (1976) found that the effect of organic matter on P sorption depended on the $\mathrm{P}$ content of the organic matter. Phosphorus sorption increased when residues contained less than $0.22 \% \mathrm{P}$ and decreased when residues contained more than $0.31 \%$ P. Sibanda and Young (1986) observed that fulvic acids caused greater reductions in P sorption than humic acids, and Bolan et al. (1994) found that reductions in $\mathrm{P}$ sorption were less pronounced with monocarboxylic acids compared to dicarboxylic and tricarboxylic acids. Ohno and Crannell (1996) concluded that the effect of DOM on P sorption was likely a function of rigidity and molecular weight of the DOM. In acid soils with exchangeable $\mathrm{Al}$ oxides, the effect of DOM on P sorption may also depend on the stability constants of the organic acids (Fox, Comerford, and McFee 1990). In addition, DOC sorption to soils has been shown to vary with hydrophobicity and molecular weight of the organic matter (Davis and Gloor 1981; Gu et al. 1995; Jardine, Weber, and McCarthy 1989; Kaiser, Guggenberger, and Zech 1996). Although we did not characterize the organic matter in our solutions, it is likely that the DOM composition of each manure solution varies (Morvan, Nicolardot, and Pean 2006) and that this variation may explain some of the observed variation in DRP sorption between the three manure solutions.

For the dairy and poultry manure solutions, large increases in $\mathrm{Al}$ and $\mathrm{Fe}$ concentrations were observed following the 24-h equilibration period (Figure 4). The $\mathrm{Al}$ content of the poultry litter was initially $0.14 \mathrm{mg} \mathrm{L}^{-1}$ but increased to values ranging from 2.2 to $11 \mathrm{mg} \mathrm{L}^{-1}$, and $\mathrm{Al}$ content of the dairy manure increased from an initial concentration of $0.02 \mathrm{~m} \mathrm{~L}^{-1}$ to values ranging from 2.4 to $7 \mathrm{mg} \mathrm{L}^{-1}$. Similar increases were also observed for $\mathrm{Fe}$. The release of $\mathrm{Al}$ and $\mathrm{Fe}$ into solution has been attributed to the dissolution of metal oxides by organic matter (Bhatti, Comerford, and Johnston 1998; Bolan et al. 1994; Fox, Comerford, and McFee 1990) and is supported by our observation of minimal release of $\mathrm{Fe}$ and $\mathrm{Al}$ for the $\mathrm{CaCl}_{2}$ solution, which lacked DOM, and the swine effluent solution, in which minimal DOC sorption was observed. The greater release of $\mathrm{Al}$ in the $\mathrm{KCl}$ solution as compared to the $\mathrm{CaCl}_{2}$ solution was likely due to the higher concentration of $\mathrm{K}$ and the fact that 

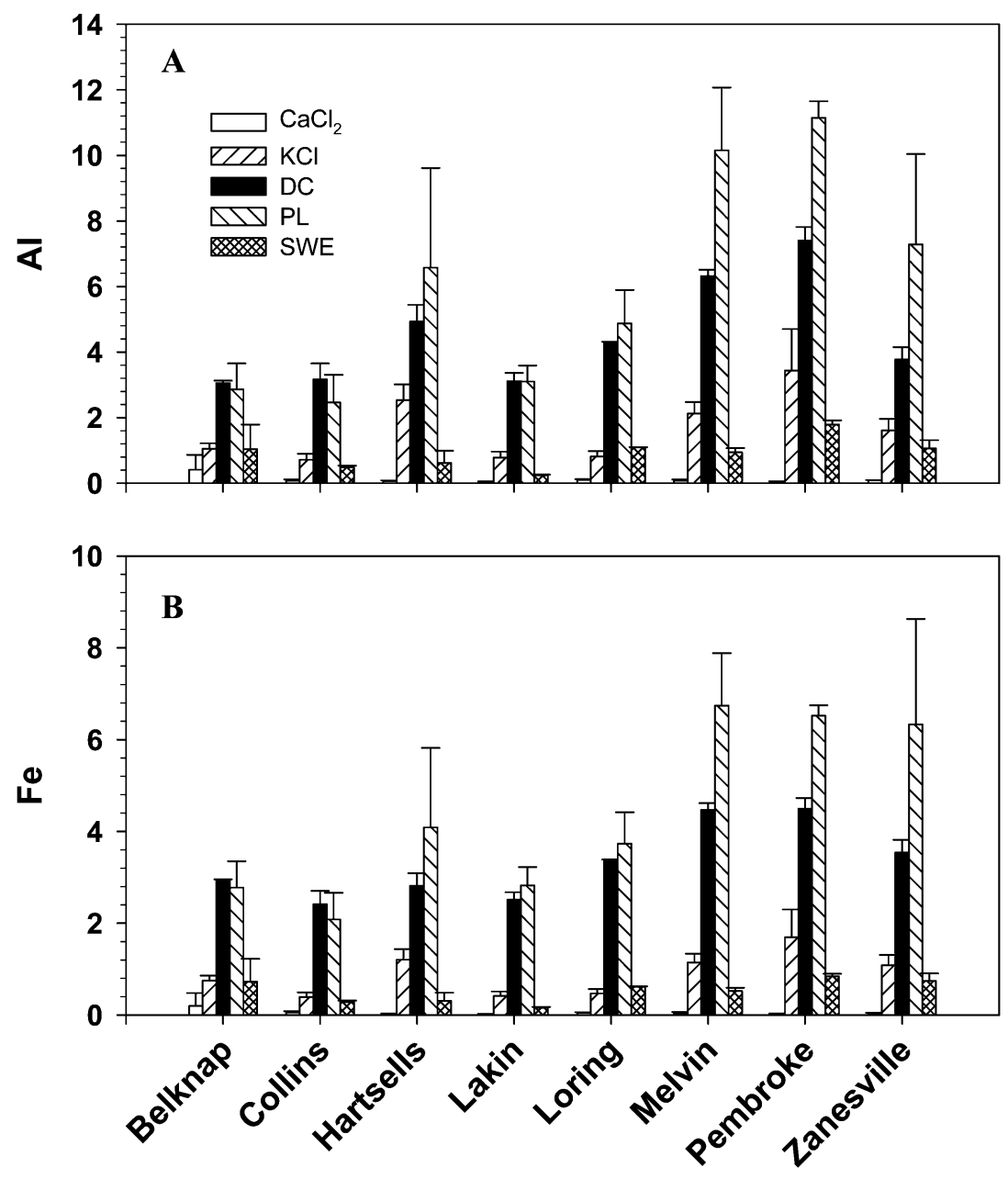

\section{Soil Type}

Figure 4. Solution concentrations of A) Al and B) Fe following the 24-h sorption experiments.

$\mathrm{K}$ has been shown to be more effective than $\mathrm{Ca}$ in displacing $\mathrm{Al}$ from soils (Chung, Zasoski, and Burau 1994).

The dissolution of metal oxides by organic matter has been shown to affect P sorption to soils. Ohno and Crannell (1996) observed that increasing concentrations of plant-derived DOM resulted in increases in $\mathrm{Al}$ concentrations in solution while at the same time causing decreases in $\mathrm{P}$ sorption. Combined with the observation of minimal release of $\mathrm{Al}$ during the application of manures that had no effect on $\mathrm{P}$ sorption, Ohno 
(Ohno and Crannel 1996; Ohno and Erich 1997) concluded that DOM was inhibiting $\mathrm{P}$ sorption by complexing with $\mathrm{Al}$ and releasing it into solution. The significant release of $\mathrm{Al}$ and $\mathrm{Fe}$ in conjunction with the reduced sorption we observed for the dairy solution is consistent with this hypothesis. However, given that the poultry litter solution had higher PSI values than the $\mathrm{CaCl}_{2}$ and $\mathrm{KCl}$ solutions in four of the eight soils, the dissolution of metal oxides apparently does not always lead to decreased DRP sorption.

For the poultry, $\mathrm{CaCl}_{2}$, and $\mathrm{KCl}$ solutions, noticeable changes in $\mathrm{pH}$ occurred following the 24-h equilibration period (Figure 5). For example, $\mathrm{pH}$ values in the poultry litter solution dropped from an initial value of 8.1 to values ranging from 7.3 to 7.5 , whereas the final $\mathrm{pH}$ values ranged from 4.7 to 6.5 and 5.6 to 7.4 for the $\mathrm{CaCl}_{2}$ and $\mathrm{KCl}$ solutions, respectively. On the other hand, $\mathrm{pH}$ values for the swine and dairy solutions were much less affected, indicating that these solutions were well buffered. Following the 24-h sorption experiment, the $\mathrm{pH}$ of the manure solutions was significantly greater $(P<0.05)$ than that of the $\mathrm{CaCl}_{2}$ for all eight soils and greater than the $\mathrm{KCl}$ solution for seven of the eight soils. Solution $\mathrm{pH}$ has been shown to be an important factor

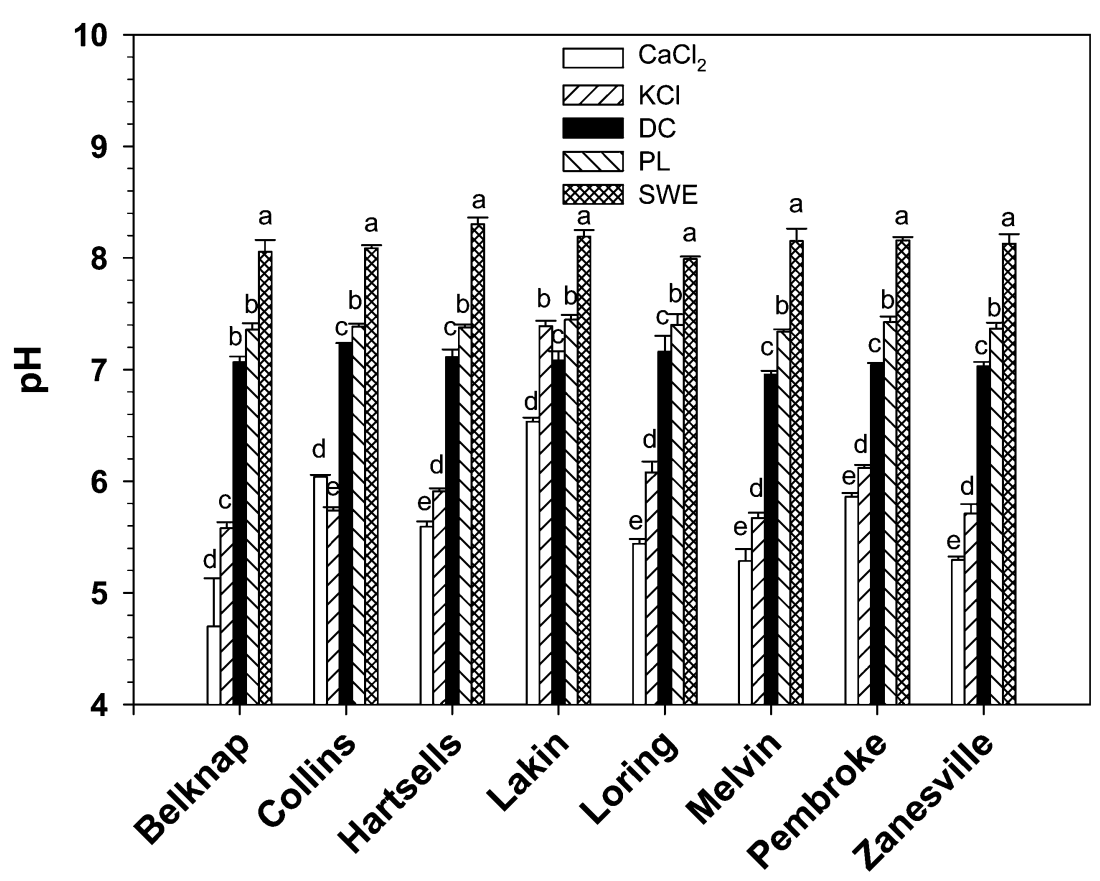

Soil Type

Figure 5. Solution $\mathrm{pH}$ values following the 24-h sorption experiments. 
controlling P sorption to soils (Amarasiri and Olsen 1973; Barrow 1983; Traina et al. 1986; Violante, Colombo, and Buondonno 1991). Solution $\mathrm{pH}$ determines the ratio of the different orthophosphate species, the charge at the soil surface, and the dominant soluble metallic-phosphate complex species (Berkheiser et al. 1980). Increased $\mathrm{pH}$ can decrease sorption by decreasing the electrostatic potential at the surface (Bowden et al. 1980) and neutralizing Fe and Al oxides. On the other hand, in solutions containing $\mathrm{Ca}$, increasing $\mathrm{pH}$ values greater than $\sim 6$ can increase sorption through precipitation of calcium phosphates (Barrow et al. 1980; Lehmann et al. 2005; Lindsay 1979; Naidu et al. 1990). Robinson and Sharpley (1996) speculated that the increase in DRP sorption in poultry litter they observed as compared to $\mathrm{KH}_{2} \mathrm{PO}_{4}$ solutions was due to precipitation of Ca phosphates. With $\mathrm{pH}$ values ranging from 8.0 to 8.3 for the swine effluent and $\mathrm{Ca}$ concentrations in excess of $50 \mathrm{mg} \mathrm{L}^{-1}$, the precipitation of $\mathrm{Ca}$ phosphates may be one reason for the elevated DRP sorption observed for this solution. The greater PSI values observed for the $\mathrm{CaCl}_{2}$ solution as compared to the $\mathrm{KCl}$ solution suggest that precipitation of $\mathrm{Ca}$ phosphates was also occurring in the $\mathrm{CaCl}_{2}$ solution even though the $\mathrm{pH}$ in this solution only exceeded 6 in three of the soils, although $\mathrm{Ca}$ phosphates have been observed to form in soils with $\mathrm{pH}$ values less than 6 (Beauchemin et al. 2003). The largest percentage difference in PSI values between the $\mathrm{CaCl}_{2}$ and $\mathrm{KCl}$ solutions did in fact occur in the Lakin soil, which had the highest $\mathrm{pH}$ (6.5) value measured for the $\mathrm{CaCl}_{2}$ solution.

\section{CONCLUSIONS}

Results from the single-point $\mathrm{P}$ addition experiments showed that the sorption of DRP in manure solutions differs significantly from that of $\mathrm{KH}_{2} \mathrm{PO}_{4}$-amended $\mathrm{CaCl}_{2}$ and $\mathrm{KCl}$ solutions and that the difference depends on manure and soil type. Our results suggest that the reduced sorption of DRP observed in the dairy manure solution was likely due to the dissolution of metal oxides by organic matter. On the other hand, the enhanced DRP sorption in the swine effluent solution was likely a result of $\mathrm{Ca}$ phosphate precipitation due to high $\mathrm{pH}$ values. The DRP sorption in the poultry litter solution was likely a combination of these processes. Regardless of the mechanism(s) involved, saturation indices based on sorption parameters obtained using $\mathrm{KH}_{2} \mathrm{PO}_{4}$-amended $\mathrm{CaCl}_{2}$ or $\mathrm{KCl}$ solutions may result in erroneous predictions of $\mathrm{P}$ loss from agricultural fields when $\mathrm{P}$ is applied in the form of animal manure. Hence, our findings support the conclusions of others who have cautioned against basing manure application rates on sorption data collected from 
inorganic P salt experiments (Marshall and Laboski 2006; Robinson and Sharpley 1996; Siddique and Robinson 2003). Also, given the variability we observed in PSI values for the different manure solutions, predictions of manure $\mathrm{P}$ sorption should be based on $\mathrm{P}$ sorption studies using the manure type to be applied to the soil. Additional studies are needed to better understand how the various components in animal manures affect P sorption to soils.

\section{ACKNOWLEDGMENTS}

This research was part of USDA-ARS National Program 206: Manure and By-product Utilization. We thank Tinesha Mack, Jason Simmons, and Stacy Antle for soil collection and sample analyses. Mention of trade names or commercial products is solely for the description of experimental procedures and does not imply recommendation or endorsement by the U.S. Department of Agriculture.

\section{REFERENCES}

Amarasiri, S. L., and S. R. Olsen. 1973. Liming as related to solubility of P and plant growth in an acid tropical soil. Soil Science Society of America Journal 37:716-720.

Bache, B. W., and E. G. Williams. 1971. A phosphate sorption index for soils. Journal of Soil Science 22:289-301.

Barrow, N. J. 1983. A mechanistic model for describing the sorption and desorption of phosphate by soil. Journal of Soil Science 34:733-750.

Barrow, N. J., J. W. Bowden, A. M. Posner, and J. P. Quirk. 1980. Describing the effects of electrolytes on adsorption of phosphate by a variable charge surface. Australian Journal of Soil Research 18:395-404.

Beauchemin, S., D. Hesterberg, J. Chou, M. Beauchemin, R. R. Simard, and D. E. Sayers. 2003. Speciation of phosphorus-enriched agricultural soils using $\mathrm{x}$ ray absorption near-edge structure spectroscopy and chemical fractionation. Journal of Environmental Quality 32:1809-1819.

Berkheiser, V. E., J. J. Street, P. S. C. Rao, and T. L. Yuan. 1980. Partitioning of inorganic orthophosphate in soil-water systems. CRC Critical Reviews in Environmental Control 10:179-224.

Bhatti, J. S., N. B. Comerford, and C. T. Johnston. 1998. Influence of oxalate and soil organic matter on sorption and desorption of phosphate onto a spodic horizon. Soil Science Society of America Journal 62:1089-1095.

Bolan, N. S., R. Naidu, S. Mahimairaja, and S. Baskaran. 1994. Influence of lowmolecular-weight organic acids on the solubilization of phosphates. Biology and Fertility of Soils 18:311-319.

Borggaard, O. K., S. S. Jorgensen, J. P. Moberg, and B. Raben-Lange. 1990. Influence of organic matter on phosphate adsorption by aluminum and iron oxides in sandy soils. Journal of Soil Science 41:443-449. 
Borling, K., E. Otabbong, and E. Barberis. 2001. Phosphorus sorption in relation to soil properties in some cultivated Swedish soils. Nutrient Cycling in Agroecosystems 59:39-46.

Bowden, J. W., S. Nagarajah, N. J. Barrow, and J. P. Quirk. 1980. Describing the adsorption of phosphate, citrate, and selenite on a variable-charge mineral surface. Australian Journal of Soil Research 18:49-60.

Burkitt, L. L., C. J. P. Gourley, M. C. Hannah, and P. W. G. Sale. 2006. Assessing alternative approaches to predicting soil phosphorus sorption. Soil Use and Management 22:325-333.

Campbell, L. B., and G. J. Racz. 1975. Organic and inorganic P content, movement, and mineralization of $\mathrm{P}$ in soil beneath a feedlot. Canadian Journal of Soil Science 55:457-466.

Chung, J.-B., R. J. Zasoski, and R. G. Burau. 1994. Aluminum-potassium and aluminum-calcium exchange equilibria in bulk and rhizosphere soil. Soil Science Society of America Journal 58:1376-1382.

Curtin, D., J. K. Syers, and N. S. Bolan. 1992. Phosphate sorption by soil in relation to exchangeable cation composition and pH. Australian Journal of Soil Research 31:137-149.

D'Angelo, E. M., M. V. Vandiviere, W. O. Thom, and F. Sikora. 2003. Estimating soil phosphorus requirements and limits from oxalate extract data. Journal of Environmental Quality 32:1082-1088.

Davis, J. A., and R. Gloor. 1981. Adsorption of dissolved organics in lake water by aluminum oxide: Effect of molecular weight. Environmental Science and Technology 15:1223-1229.

Eghball, B., G. D. Binford, and D. D. Baltensperger. 1996. Phosphorus movement and adsorption in a soil receiving long-term manure and fertilizer application. Journal of Environmental Quality 25:1339-1343.

Fox, T. R., N. B. Comerford, and W. W. McFee. 1990. Phosphorus and aluminum release from a spodic horizon mediated by organic acids. Soil Science Society of America Journal 54:1763-1767.

Griffin, R. A., and J. J. Jurinak. 1973. Estimation of activity coefficients from the electrical conductivity of natural aquatic systems and soil extracts. Soil Science 116:26-30.

Gu, B. J., J. Schmitt, Z. Chen, L. Liang, and J. F. McCarthy. 1995. Adsorption and desorption of different organic matter fractions on iron oxide. Geochimica et Cosmochimica Acta 59:219-229.

Guppy, C. N., N. W. Menzies, F. P. C. Blamey, and P. W. Moody. 2005a. Do decomposing organic matter residues reduce phosphorus sorption in highly weathered soils? Soil Science Society of America Journal 69:14051400 .

Guppy, C. N., N. W. Menzies, P. W. Moody, and F. P. C. Blamey. 2005b. Competitive sorption reactions between phosphorus and organic matter in soil: A review. Australian Journal of Soil Research 43:189-202.

Harter, R. D. 1969. Phosphorus adsorption sites in soils. Soil Science Society of America Proceedings 33:630-632.

Hooda, P. S., A. R. Rendell, A. C. Edwards, P. J. A. Withers, M. N. Aitken, and V. W. Truesdale. 2000. Relating soil phosphorus indices to potential phosphorus release to water. Journal of Environmental Quality 29:1166-1171. 
Hsu, P. H. 1964. Adsorption of phosphorus by aluminum and iron in soils. Soil Science Society of America Proceedings 28:474-478.

Jardine, P. M., N. L. Weber, and J. F. McCarthy. 1989. Mechanisms of dissolved organic carbon adsorption on soil. Soil Science Society of America Journal 53:1378-1385.

Jensen, M. B., T. B. Olsen, H. C. B. Hansen, and J. Magid. 2000. Dissolved and particulate phosphorus in leachate from structured soil amended with fresh cattle faeces. Nutrient Cycling in Agroecosystems 56:253-261.

Kaiser, K. G., G. Guggenberger, and W. Zech. 1996. Sorption of DOM and DOM fractions to forest soils. Geoderma 74:281-303.

Kleinman, P. J. A., and A. N. Sharpley. 2002. Estimating soil phosphorus sorption saturation data from Mehlich-3 data. Communication in Soil Science and Plant Analysis 33:1825-1839.

Lehmann, J., Z. Lan, C. Hyland, S. Sato, D. Solomon, and Q. M. Ketterings. 2005. Long-term dynamics of phosphorus forms and retention in manureamended soils. Environmental Science and Technology 39:6672-6680.

Lindsay, W. L. 1979. Chemical equilibria in soils. New York: John Wiley \& Sons.

Marshall, S. K., and C. A. M. Laboski. 2006. Sorption of inorganic and total phosphorus from dairy and swine slurries to soil. Journal of Environmental Quality 35:1836-1843.

McDowell, R. W., and A. N. Sharpley. 2004. Variation of phosphorus leached from Pennsylvanian soils amended with manures, composts, or inorganic fertilizer. Agriculture, Ecosystems and Environment 102:17-27.

Mehlich, A. 1984. Mehlich 3 soil test extractant. Communication in Soil Science and Plant Analysis 15:1409-1416.

Morvan, T., B. Nicolardot, and L. Pean. 2006. Biochemical composition and kinetics of $\mathrm{C}$ and $\mathrm{N}$ mineralization of animal wastes: A typological approach. Biology and Fertility of Soils 42:513-522.

Murphy, J., and H. P. Riley. 1962. A modified single solution method for the determination of phosphate in natural waters. Analytica Chimica Acta 27:31-36.

Naidu, R., J. K. Syers, R. W. Tillman, and J. H. Kirkman. 1990. Effect of liming on phosphate sorption by acid soils. Journal of Soil Science 41:165-175.

Nair, P. S., T. J. Logan, A. N. Sharpley, L. E. Sommers, M. A. Tabatabai, and T. L. Yuan. 1984. Interlaboratory comparison of a standardized phosphorus adsorption procedure. Journal of Environmental Quality 3:591-595.

Ohno, T., and B. S. Crannell. 1996. Green and animal manure-derived dissolved organic matter effects on phosphorus sorption. Journal of Environmental Quality 25:1137-1143.

Ohno, T., and M. S. Erich. 1997. Inhibitory effects of crop residue derived organic ligands on phosphate adsorption kinetics. Journal of Environmental Quality 26:889-895.

Parry, R. 1998. Agricultural phosphorus and water quality: A U.S. Environmental Protection Agency perspective. Journal of Environmental Quality 27:258-261.

Pierzynski, G. M., T. J. Logan, S. J. Traina, and J. M. Bigham. 1990. Phosphorus chemistry and mineralogy in excessively fertilized soils: Quantitative analysis of phosphorus-rich particles. Soil Science Society of America Journal 54:15761583 . 
Redding, M. R., T. Shatte, and K. Bell. 2006. Soil sorption-desorption of phosphorus from piggery effluent compared with inorganic sources. European Journal of Soil Science 57:134-146.

Reddy, K. R., M. R. Overcash, R. Khaleel, and P. W. Westerman. 1980. Phosphorus adsorption-desorption characteristics of two soils utilized for disposal of animal wastes. Journal of Environmental Quality 9:86-92.

Robinson, J. S., and A. N. Sharpley. 1996. Reaction in soil of phosphorus released from poultry litter. Soil Science Society of America Journal 60:15831588.

Sanyal, S. K., S. K. De Datta, and P. Y. Chan. 1993. Phosphate adsorption and desorption behavior of some acidic soils of south and southeast Asia. Soil Science Society of America Journal 57:937-945.

SAS Institute. 2003. SAS user's guide. Cary, N.C.: SAS Institute.

Sauer, T. J., T. C. Daniel, D. J. Nichols, C. P. West, J. P. A. Moore, and G. L. Wheeler. 2000. Runoff water quality from poultry-treated pasture and forest sites. Journal of Environmental Quality 29:515-521.

Sharpley, A., and B. Moyer. 2000. Phosphorus forms in manure and compost and their release during simulated rainfall. Journal of Environmental Quality 29:1462-1469.

Sharpley, A. N. 1995. Dependence of runoff phosphorus on extractable soil phosphorus. Journal of Environmental Quality 24:920-926.

Sibanda, H. M., and S. D. Young. 1986. Competitive adsorption of humus acids and phosphate on goethite, gibbsite, and two tropical soils. European Journal of Soil Science 37:197-204.

Siddique, M. T., and J. S. Robinson. 2003. Phosphorus sorption and availability in soils amended with animal manures and sewage sludge. Journal of Environmental Quality 32:1114-1121.

Singh, B. B., and J. P. Jones. 1976. Phosphorus sorption and desorption characteristics of soil as affected by organic residues. Soil Science Society of America Journal 40:389-394.

Traina, S. J., G. Sposito, D. Hesterberg, and U. Kafkafi. 1986. Effects of pH and organic acids on orthophosphate solubility in an acidic, montmorillonite soil. Soil Science Society of America Journal 50:45-52.

Van der Zee, S. E. A. T. M., and W. H. Van Riemsdijk. 1986. Sorption kinetics and transport of phosphate in sandy soil. Geoderma 38:293-309.

Violante, A., C. Colombo, and A. Buondonno. 1991. Competitive adsorption of phosphate and oxalate by aluminum oxides. Soil Science Society of America Journal 55:65-70.

Violante, A., and P. M. Huang. 1989. Influence of oxidation treatments on surface properties and reactivities of short-range ordered precipitation products of aluminum. Soil Science Society of America Journal 53:1402-1407.

Zhou, M., R. D. Rhue, and W. G. Harris. 1997. Phosphorus sorption characteristics of $\mathrm{Bh}$ and $\mathrm{Bt}$ horizons from sandy coastal plain soils. Soil Science Society of America Journal 61:1364-1369. 